Studia nad Autorytaryzmem i Totalitaryzmem 42, nr 4

Wrocław 2020

https://doi.org/10.19195/2300-7249.42.4.7

\author{
JOANNA KUŹMICKA-SULIKOWSKA \\ ORCID: 0000-0002-7699-5150 \\ Uniwersytet Wrocławski \\ joanna.kuzmicka-sulikowska@uwr.edu.pl
}

\title{
Postautorytarna trauma jako czynnik sprawczy przemian mechanizmu przedawnienia roszczeń w Polsce. Częśśc 1
}

\begin{abstract}
Abstrakt: Trauma po życiu w państwie autorytarnym, a w istotnym okresie — wręcz totalitarnym, spowodowała, że wiele instytucji funkcjonujących wówczas w polskim prawie na fali przemian ustrojowych z 1989 roku i związanych z nimi modyfikacji obowiązujących regulacji prawnych zostało zastąpione rozwiązaniami neoliberalnymi, często w ramach ogólnej tendencji do odrzucania naleciałości postradzieckich i przyjmowania w ich miejsce konstrukcji wzorowanych na rozwiązaniach zachodnioeuropejskich. Proces ten nie ominął przepisów dotyczących przedawnienia roszczeń majątkowych. Przejawiło się to między innymi w odejściu od modelu, w ramach którego upływ terminu przedawnienia roszczenia był uwzględniany przez sąd $\mathrm{z}$ urzędu, i zastąpieniu go rozwiązaniem dopuszczającym branie tej okoliczności przez sąd pod uwagę tylko w razie podniesienia zarzutu przedawnienia przez podmiot, przeciwko któremu dane roszczenie przysługuje. W niniejszym artykule podjęto tę problematykę, aby pokazać ciekawą ewolucję, jaka nastąpiła w tym zakresie, zarówno w kontekście praktyki stosowania prawa, jak i następnie zmian ustawodawczych. Zasługuje ona na uwagę, ponieważ przyjęte liberalne rozwiązanie okazało się nie do końca odpowiadać potrzebom społecznym, sądy w swym orzecznictwie przyjęły możliwość oceniania, czy podniesienie przez pozwanego zarzutu przedawnienia nie stanowi nadużycia prawa, a dodatkowo nastąpił tu - przynajmniej częściowy (w zakresie roszczeń dochodzonych przez przedsiębiorców od konsumentów) - powrót do rozwiązania przewidującego uwzględnianie przez sąd jednak z urzędu upływu terminu przedawnienia dochodzonego przed nim roszczenia. Przyjęta w 1990 roku liberalna konstrukcja została więc, jak dotąd częściowo, wyparta przez rozwiązanie funkcjonujące w ustroju autorytarnym, na co niewątpliwie miał wpływ opiekuńczy, prosocjalny charakter tego ostatniego rozwiązania, wpisujący się też dobrze w aktualne nurty populistyczne.

$\mathrm{Z}$ uwagi na konieczność poruszenia w ramach tak zakreślonej tematyki rozważań kilku wątków tekst został podzielony na dwie części. W pierwszej pokazana została przemiana wspomnianego rozwiązania normatywnego, dokonana w 1990 roku, a także podstawowe aspekty wiążące się z funkcjonowaniem dwóch konkurujących w rozważanej kwestii rozwiązań, to jest uwzględnianiem przez sąd upływu terminu przedawnienia z urzędu bądź na zarzut pozwanego. W drugiej części pokazano natomiast kolejne przemiany funkcjonowania rozwiązania przyjętego w 1990 roku aż do
\end{abstract}


wskazania obecnie obowiązującej regulacji w analizowanym zakresie wraz z refleksjami na temat ewolucji odnośnych rozwiązań prawnych.

Słowa kluczowe: przedawnienie, zarzut przedawnienia, roszczenia majątkowe, przedawnione roszczenia, skutki upływu terminu przedawnienia.

\title{
POST-AUTHORITARIAN TRAUMA AS A CAUSATIVE FACTOR OF CHANGES IN THE MECHANISM OF LIMITATION OF CLAIMS IN POLAND. PART 1
}

\begin{abstract}
The trauma after the post-authoritarian, and during a significant period even a totalitarian state, resulted in many institutions functioning at that time in Polish law on the wave of the political transformations of 1989 and the related modifications of the binding legal regulations, being replaced by neoliberal solutions, often as a part of the general tendency to reject post-Soviet accretions and replace them with structures modelled on Western European solutions. This process also included provisions on the limitation of claims. This was manifested i.a. in departing from the model under which the expiry of the limitation period was taken into account by the court ex officio and replacing it with a solution allowing the court to take this circumstance into account only in the event when a plea of limitation is raised by the defendant. This article deals with this issue to show an interesting evolution that has taken place in this area, both in the context of applying the law and subsequent legislative changes. It is deserving of attention because the adopted liberal solution(s) turned out not to fully meet social needs, the courts in their jurisprudence adopted the possibility of assessing whether the defendant's plea of limitation does not constitute an abuse of law, and also - at least partially (in terms of claims from consumers pursued by entrepreneurs) - returning to the solution under which the court ex officio considers the expiry of the limitation period of the claim asserted before it. Thus, the liberal structure adopted in 1990 has so far been partially replaced by the solution functioning in the authoritarian system, which was undoubtedly influenced by the caring, pro-social nature of the latter solution, which also fits well with the current populist trends.

Due to the necessity to deal with several aspects within the scope of such deliberations, the text has been divided into two parts. The first one presents the transformation of the aforementioned normative solution made in 1990, as well as the basic aspects related to the functioning of two competing solutions in the discussed issue, i.e. taking into account the expiration of the limitation period of claims by the court ex officio or on the defendant's plea. The second part covers the subsequent changes in the functioning of the solution adopted in 1990, up to the indication of the currently applicable regulation in the analysed area, with reflections on the evolution of relevant legal solutions.
\end{abstract}

Keywords: limitation, plea of limitation, property claims, time-barred claims, effects of the expiration of the limitation period.

\section{Wprowadzenie. Wpływ zmian ustrojowych w Polsce na prawo cywilne}

Przemiany polityczno-ustrojowe dokonane w Polsce w 1989 roku w sposób nieunikniony pociągnęły za sobą przeobrażenia w wielu sferach funkcjonowania społeczeństwa. Jedną z takich sfer, a przy tym narzędziem wychodzenia 
z minionego ustroju, stały się zmiany regulacji prawnej. Oprócz aktów o zasadniczym znaczeniu ustrojowym ${ }^{1}$ proces ten nie ominął unormowań odnoszących się do poszczególnych gałęzi prawa, w tym prawa cywilnego. Jeśli chodzi o to ostatnie, w omawianym kontekście na szczególną uwagę zasługuje ustawa z dnia 28 lipca 1990 roku o zmianie ustawy — Kodeks cywilny ${ }^{2}$, która istotnie przeobraziła przepisy tego kodeksu, niektóre z nich definitywnie usuwając, innym z kolei nadając nowe brzmienie. Nowelizacja ta była wyraźnie ukierunkowana na usunięcie $\mathrm{z}$ tego podstawowego dla cywilnego prawa materialnego aktu wszelkich rozwiązań nawiązujących do poprzedniego ustroju (w tym w zakresie stosowanej terminologii - na przykład z treści art. $5 \mathrm{KC}^{3}$ usunięto ${ }^{4}$ słowa „W Polskiej Rzeczypospolitej Ludowej”). Wprowadzono również wiele merytorycznych zmian, nastąpiło między innymi odejście od dotychczasowego wyróżniania typów i form własności (poprzez skreślenie art. 126-139 KC), czemu przyświecała koncepcja zrównania własności niezależnie od tego, jakiemu podmiotowi ona przysługuje ${ }^{5}$. Zarzucono dotychczas nierówne traktowanie podmiotów prawa cywilnego, socjalistyczną typologię własności i rozwiązania uprzywilejowujące własność uspołecznioną, a także konstrukcję jedności własności państwowej; wyeliminowane zostały też szczególne reguły obrotu między jednostkami gospodarki uspołecznionej ${ }^{6}$.

W literaturze przedmiotu nie budziło wątpliwości, że omawiana ustawa, gruntownie nowelizująca kodeks cywilny, służyła „oczyszczeniu” prawa cywilnego z naleciałości związanych z ustrojem komunistycznym ${ }^{7}$. Na fali tych zmian zmodyfikowano także regulacje dotyczące przedawnienia cywilnoprawnych roszczeń majątkowych, w tym zastąpiono obowiązujące do tej pory rozwiązanie przewidujące uwzględnianie upływu terminu przedawnienia roszczenia przez sąd z urzędu takim, w ramach którego upływ terminu przedawnienia dochodzonego przed sądem roszczenia mógł być wzięty przez tenże sąd pod uwagę tylko w razie podniesienia stosownego zarzutu w tej kwestii przez tego, wobec kogo roszczenie to było dochodzone ${ }^{8}$. W literaturze uznawano to za przejaw odrzucenia naleciałości posttotalitarnych, wzorowanych na rozwiązaniach radzieckich, i przyjęcia konstrukcji

${ }^{1}$ Na przykład ustawa z dnia 29 grudnia 1989 roku o zmianie Konstytucji PRL (Dz.U. z 1989 r. Nr 75, poz. 444 ze zm.).

2 Dz.U. z 1990 r. Nr 55, poz. 321; ustawa ta weszła w życie 1 października 1990 roku.

3 Ustawa z dnia 23 kwietnia 1964 roku — Kodeks cywilny (tekst jedn. Dz.U. z 2020 r. poz. 1740 ze zm.), dalej: KC.

${ }^{4} \mathrm{Na}$ mocy art. 1 pkt 3 powołanej ustawy z 28 lipca 1990 roku o zmianie ustawy - Kodeks cywilny.

5 E. Gniewek, Prawo rzeczowe, Warszawa 2006, s. 34.

6 Z. Radwański, Prawo cywilne - część ogólna, Warszawa 2007, s. 29.

7 A. Stelmachowski, Zarys teorii prawa cywilnego, Warszawa 1998, s. 76.

${ }^{8}$ Co nastąpiło w drodze zmiany brzmienia art. $117 \mathrm{KC}$, dokonanego na podstawie art. 1 pkt 17 ustawy z dnia 28 lipca 1990 roku o zmianie ustawy — Kodeks cywilny. 
prawnej funkcjonującej w prawodawstwach państw zachodnich ${ }^{9}$. Warto jednak odnotować, że w późniejszym czasie pojawiły się też refleksje o pewnym automatyzmie, jaki można dostrzec na tle tych zmian ustawodawczych, polegającym na tym, że rozwiązania funkcjonujące w okresie socjalizmu już z samego powodu takiej ich proweniencji traktowano jako złe i wymagające zmiany ${ }^{10}$. Tymczasem stawiane bywają pytania o to, czy we wszystkich aspektach przyjmowanie takiego założenia było zasadne i czy aby neoliberalne dążenie do zlikwidowania socjalizmu państwowego nie doprowadziło do zniszczenia elementów z czasu socjalizmu, które były korzystne ze społecznego punktu widzenia, jak na przykład mechanizmy zrównywania sytuacji ekonomicznej członków społeczeństwa. Twierdzi się wręcz, że niektóre zmiany dokonane w ramach transformacji ustrojowej w Polsce tylko zwiększyły nierówności i zadziałały na niekorzyść tych, którzy walczyli o obalenie socjalistycznego państwa ${ }^{11}$. Podnosi się też, że nie każde rozwiązane funkcjonujące w ustroju, od którego się odchodzi, powinno być z tej tylko przyczyny traktowane jako patologia wymagająca usunięcia ${ }^{12}$.

Na tym tle warto poczynić refleksję, czy aby zmiana regulacji prawnej dotyczącej sposobu uwzględniania upływu terminu przedawnienia roszczeń w kodeksie cywilnym nie stanowi przykładu takiej właśnie sytuacji. W tym obszarze w 1990 roku nastąpiło bowiem przejście od konstrukcji normatywnej zastrzegającej co do zasady uwzględnianie upływu terminu przedawnienia roszczenia przez sąd z urzędu na rzecz rozwiązania, na gruncie którego aspekt ten mógł być wzięty przez sąd pod uwagę jedynie w wypadku podniesienia zarzutu przedawnienia przez tego, przeciwko komu roszczenie przysługuje, przy czym to ostatnie rozwiązanie bywa postrzegane jako korzystniejsze dla osób bardziej zaradnych, wykształconych, mających dostęp do wiedzy prawniczej lub na tyle zamożnych, że mogą skorzystać z pomocy profesjonalnego prawnika.

\section{Aspekty socjalne mechanizmu przedawnienia roszczeń majątkowych}

Jako przemawiający za uwzględnianiem upływu terminu przedawnienia dochodzonego roszczenia przez sąd z urzędu podnosi się przede wszystkim argument,

9 Zob. S. Wójcik, Przedawnienie w prawie cywilnym po zmianie kodeksu cywilnego ustawa z 28 lipca 1990 r., „Przegląd Sądowy” 1991, nr 1-2, s. 48; A. Brzozowski, Nowa regulacja przedawnienia w prawie cywilnym, „Państwo i Prawo” 1992, nr 3, s. 25-26. Zob. też J. Kruszyńska-Kola, Ratio przedawnienia, Warszawa 2020, s. 451.

10 E. Charkiewicz, Od komunizmu do neoliberalizmu. Technologie transformacji, [w:] Zniewolony umyst 2. Neoliberalizm i jego krytyki, red. E. Majewska, J. Sowa, Kraków 2007, s. 61.

11 E. Dunn, Prywatyzujac Polske, Warszawa 2008, s. 193.

12 R. Mańko, Demons of the past? Legal survivals of the socialist legal tradition in contemporary Polish private law, [w:] Law and Critique in Central Europe. Questioning the Past, Resisting the Present, red. R. Mańko, C. Cercel, A. Sulikowski, Oxford 2016, s. 86-89. 
że jest to rozwiązanie równo traktujące wszystkich, wobec czego - w przeciwieństwie do rozwiązania przyjmującego uwzględnianie upływu terminu przedawnienia roszczenia tylko na zarzut — nie są w jego przypadku stawiane w gorszej sytuacji osoby czy to same niemające wystarczającej wiedzy, czy też nieposiadające wystarczających zasobów finansowych, by móc sobie pozwolić na skorzystanie z pomocy profesjonalnego prawnika. Przy konstrukcji, w której upływ terminu przedawnienia roszczenia jest uwzględniany z urzędu, to bowiem nie ten, od kogo dochodzone jest dane roszczenie, musi znać przepisy - w tym między innymi umieć ustalić termin przedawnienia żądanego od niego roszczenia, początek jego biegu, jak też określić, czy doszło do zdarzeń wpływających na jego bieg (na przykład powodujących zawieszenie albo przerwanie biegu tego terminu), a także wiedzieć, że chcąc uniknąć zaspokojenia przedawnionego roszczenia, musi podnieść zarzut przedawnienia, a przy tym mieć świadomość, jak to uczynić (względnie być osobą dysponującą odpowiednimi zasobami finansowymi, pozwalającymi na zaangażowanie do jej reprezentowania profesjonalnego prawnika, na przykład radcy prawnego czy adwokata, a przy tym mającą świadomość potrzeby skorzystania z takiej pomocy). Wręcz przeciwnie, kiedy obowiązuje rozwiązanie, w ramach którego sąd ma brać pod uwagę z urzędu upływ terminu przedawnienia dochodzonego przed nim roszczenia, wówczas ten, od kogo to roszczenie jest dochodzone, może ani nie mieć wiedzy we wspomnianym powyżej zakresie, ani nie korzystać z pomocy prawnika i w związku z tym nie podjąć żadnych kroków odnośnie do tego, że dochodzone od niego roszczenie jest przedawnione, a mimo to ta okoliczność zostanie wzięta pod uwagę przez sąd, gdyż musi on wówczas uczynić to z urzędu. Często też narracja preferująca rozwiązanie, w ramach którego upływ terminu przedawnienia roszczenia jest brany pod uwagę z urzędu, prowadzona jest poprzez ukazywanie jej jako remedium na wady modelu, w którym okoliczność ta może być brana przez sąd pod uwagę tylko w razie podniesienia zarzutu przez tego, przeciwko komu roszczenie przysługuje. Przykładowo zwraca się uwagę, że przy obowiązywaniu tego ostatniego modelu dochodzi do trudnej do wytłumaczenia społeczeństwu rozbieżności w orzecznictwie sądowym w porównywalnych sprawach dotyczących przedawnionych roszczeń w zależności od tego, czy w danym postępowaniu doszło do podniesienia przez pozwanego zarzutu przedawnienia, czy też nie (zależnie od tego, czy miał on wystarczającą wiedzę $\mathrm{w}$ zakresie przepisów dotyczących przedawnienia bądź reprezentował go wykwalifikowany pełnomocnik), a w konsekwencji do negatywnych odczuć społecznych, w tym utraty zaufania do tego, że w sądzie sprawa znajdzie sprawiedliwe rozstrzygnięcie ${ }^{13}$. Niekiedy wprost konstrukcja prawna, w ramach której sąd może wziąć pod uwagę okoliczność, że dochodzone przed nim roszczenie jest przedawnione jedynie wtedy, gdy ten, wobec kogo roszczenie jest dochodzone, podniesie zarzut przedawnienia, była wręcz postrzegana zwłaszcza w okresie państwa autorytarnego — jako rozwiązanie służące burżuazji, uderzające $\mathrm{w}$ osoby niedysponujące środkami finansowymi na skorzystanie z usług

13 J. Cagara, Na temat przedawnienia i prekluzji stów kilka, „Nowe Prawo” 1961, nr 6, s. 768. 
adwokata $^{14}$. Kontrastowano to z konstrukcją przewidującą uwzględnianie upływu terminu przedawnienia $\mathrm{z}$ urzędu, prezentowaną jako środek zapobiegający wykorzystywaniu instytucji przedawnienia jako narzędzia wyzysku ${ }^{15}$.

Jak już wspomniano, takie rozwiązanie, przewidujące — przynajmniej co do zasady - uwzględnianie upływu terminu przedawnienia roszczenia dochodzonego przed sądem przez tenże sąd z urzędu, obowiązywało w pierwotnym brzmieniu kodeksu cywilnego. Przewidywano tam bowiem, że w stosunkach między jednostkami gospodarki uspołecznionej podlegającymi państwowemu arbitrażowi gospodarczemu (a więc $\mathrm{w}$ tak zwanym obrocie uspołecznionym) wraz $\mathrm{z}$ upływem terminu przedawnienia roszczenie wygasa, natomiast $\mathrm{w}$ ramach innych stosunków (to jest w ramach tak zwanego obrotu powszechnego) przepis zakazywał dochodzenia przedawnionego roszczenia, z wyjątkiem wypadków, gdy ten, przeciwko komu roszczenie przysługuje, zrzekł się korzystania z przedawnienia, z tym że zrzeczenie takie nie mogło nastąpić przed upływem terminu przedawnienia (co wynikało z art. $117 \S 2 \mathrm{KC}$ w pierwotnym brzmieniu). Sąd, państwowa komisja arbitrażowa bądź inny organ powołany do rozpoznawania spraw danego rodzaju miał uwzględniać upływ terminu przedawnienia z urzędu; zastrzegano jednak możliwe odstępstwo od tej reguły, mianowicie wymienione podmioty mogły wyjątkowo nie uwzględnić upływu terminu przedawnienia, gdy termin przedawnienia danego roszczenia nie przekraczał trzech lat, a opóźnienie w dochodzeniu roszczenia było usprawiedliwione wyjątkowymi okolicznościami i nie było nadmierne (art. $117 \S 3 \mathrm{KC}$ w pierwotnym brzmieniu tego kodeksu).

Konstrukcja przyjęta odnośnie do sposobu uwzględniania upływu terminu przedawnienia roszczenia $\mathrm{w}$ pierwotnym brzmieniu kodeksu cywilnego była więc złożona, $\mathrm{w}$ tym podnoszono trudności z zakwalifikowaniem mechanizmów przyjętych w ramach obrotu powszechnego, gdzie ten, przeciwko komu roszczenie przysługiwało, mógł zrzec się korzystania z przedawnienia i dopiero jeśli tego nie uczynił, sąd z urzędu brał pod uwagę upływ terminu przedawnienia roszczenia, jednak w wyjątkowych przypadkach (już wskazanych, regulowanych ówczesnym art. $117 \S 3 \mathrm{KC}$ ) mógł tego nie uczynić. Wątpliwości budziło zarówno to, jaką instytucję prawną kreuje to ostatnie rozwiązanie (na przykład czy występuje tu element możliwości reagowania sądu na nadużycie prawa podmiotowego), jak i ograniczenie jej zastosowania do terminów przedawnienia nie dłuższych niż trzy lata. Również w tej złożoności tego rozwiązania, a także jego niespójności oraz braku możliwości nieuwzględnienia przez sąd upływu terminu przedawnienia w stosunku do terminów dłuższych niż trzy lata, upatrywana bywa przyczyna odejścia przez ustawodawcę w 1990 roku od rozwiązania przewidującego uwzględnianie upływu terminu przedawnienia roszczenia przez sąd $\mathrm{z}$ urzędu ${ }^{16}$. Niemniej nie powinno też

14 S. Szer, Prawo cywilne - część ogólna, Warszawa 1950, s. 230.

15 A. Wolter, Prawo cywilne - część ogólna, Kraków-Lublin 1953, s. 265.

16 B. Kordasiewicz, [w:] System Prawa Prywatnego, t. 2. Prawo cywilne - część ogólna, red. Z. Radwański, Warszawa 2008, s. 602. 
uchodzić uwadze, że samemu rozwiązaniu zakładającemu uwzględnianie upływu terminu przedawnienia roszczenia przez sąd z urzędu przypisywano - jak wcześniej wspominano - z reguły proweniencję z prawa radzieckiego ${ }^{17}$ i dlatego na fali przemian ustrojowych w Polsce, na mocy powoływanej już ustawy nowelizującej kodeks cywilny z 28 lipca 1990 roku, wyeliminowano to rozwiązanie na rzecz konstrukcji, w ramach której upływ terminu przedawnienia roszczenia mógł być przez sąd wzięty pod uwagę tylko w razie podniesienia zarzutu przedawnienia przez tego, wobec kogo dane roszczenie jest dochodzone.

Wprowadzone w 1990 roku rozwiązanie przewidujące — naówczas jednolicie - możliwość uwzględnienia przez sąd upływu terminu przedawnienia dochodzonego przed nim roszczenia jedynie $\mathrm{w}$ razie podniesienia stosownego zarzutu $\mathrm{w}$ tej kwestii przez tego, przeciwko komu roszczenie jest dochodzone, postrzegane było - jak wskazano - jako zwrot ku rozwiązaniu przyjmowanemu w państwa zachodnich. Trzeba jednak odnotować, że nie było to rozwiązanie w prawie polskim nowe, albowiem funkcjonowało już ono na gruncie kodeksu zobowiązań ${ }^{18}$ (w którym art. $273 \S 2 \mathrm{KZ}$ wręcz zakazywał sądowi brania z urzędu pod uwagę upływu terminu przedawnienia) czy ustawy z dnia 18 lipca 1950 roku - Przepisy ogólne prawa cywilnego ${ }^{19}$ (przy czym obowiązywanie omawianego rozwiązania wyprowadzano wówczas $\mathrm{w}$ drodze interpretacji przede wszystkim $\mathrm{z}$ art. 106, art. $107 \S 1 \mathrm{i}$ art. 115 tego aktu prawnego ${ }^{20}$ ).

Nieraz w ramach argumentacji na rzecz takiego właśnie rozwiązania, w ramach którego upływ terminu przedawnienia roszczenia może być przez sąd wzięty pod uwagę tylko wtedy, gdy ten, przeciwko komu roszczenie przysługuje, podniesie stosowny zarzut w tej kwestii, przebijają się wątki neoliberalne. Tu bowiem to z jednostki czyni się dysponenta skutków upływu terminu przedawnienia przysługującego wobec niej roszczenia — to do niej należy decyzja, czy podniesie zarzut przedawnienia, czy też może zrzeknie się korzystania z tego zarzutu (na co pozwala art. $117 \S 2 \mathrm{KC}$, z tym że jest to dopuszczalne jedynie po upływie terminu przedawnienia danego roszczenia; dokonane wcześniej jest nieważne), czy w ogóle, nie dokonując zrzeczenia się tego zarzutu, nie podniesie go jednak, lecz podejmie w procesie merytoryczną obronę wobec argumentów powoda ${ }^{21}$. Podnosi się

17 Zob. np. A. Szpunar, Zrzeczenie się korzystania z przedawnienia, „Palestra” 1980, nr 4-5, s. 16; idem, Uwagi o zrzeczeniu się zarzutu przedawnienia, „Rejent” 2002, nr 10, s. 17.

18 Rozporządzenie Prezydenta Rzeczypospolitej Polskiej z dnia 27 października 1933 roku Kodeks zobowiązań (Dz.U. z 1933 r. Nr 82, poz. 598 ze zm.), dalej: KZ.

19 Dz.U. z 1950 r. Nr 34, poz. 311.

20 J. Gwiazdomorski, Podstawowe problemy przedawnienia, „Nowe Prawo” 1955, nr 1, s. 16.

21 Jako przykład takiej sytuacji nieraz przywołuje się w literaturze sytuację pozwanego lekarza, który może chcieć dążyć do utrzymania swojego dobrego imienia i wobec tego dążyć do merytorycznego wykazania, że nie dopuścił się błędu medycznego i nie ponosi odpowiedzialności cywilnej za doznany przez daną osobę uszczerbek, tak, aby to stało się podstawą oddalenia powództwa wytoczonego przeciwko niemu, a nie przedawnienie dochodzonego roszczenia (A. Szpunar, Zrzeczenie..., s. 16; J. Gwiazdomorski, op. cit., s. 18). Inna rzecz, że - przynajmniej w obecnych 
też między innymi, że rozwiązanie, w którym upływ terminu przedawnienia podlega uwzględnieniu tylko na zarzut pozwanego, lepiej komponuje się z modelem, w którym przedawnione roszczenie nie wygasa, lecz ulega przekształceniu w zobowiązanie naturalne, a także ze swobodą dysponowania zarzutem przedawnienia przez osobę, przeciwko której roszczenie przysługuje, także poza procesem ${ }^{22}$.

Okazało się jednak, że wprowadzone w 1990 roku rozwiązanie nie tylko nie wytrwało „w czystej postaci” w praktyce stosowania prawa, ale i zaczęło być negatywnie odbierane społecznie, co w konsekwencji doprowadziło do częściowej, bardzo symptomatycznej, zmiany regulacji prawnej dotyczącej tej materii mianowicie do powrotu (choć w ograniczonym zakresie) do rozwiązania, w którym upływ terminu przedawnienia jest uwzględniany przez sąd z urzędu, o czym szerzej będzie mowa w drugiej części artykułu.

\section{Bibliografia}

Brzozowski A., Nowa regulacja przedawnienia w prawie cywilnym, „Państwo i Prawo” 1992, nr 3. Cagara J., Na temat przedawnienia i prekluzji stów kilka, „Nowe Prawo” 1961, nr 6.

Charkiewicz E., Od komunizmu do neoliberalizmu. Technologie transformacji, [w:] Zniewolony umyst 2. Neoliberalizm i jego krytyki, red. E. Majewska, J. Sowa, Kraków 2007.

Dunn E., Prywatyzując Polskę, Warszawa 2008.

Gniewek E., Prawo rzeczowe, Warszawa 2006.

Gwiazdomorski J., Podstawowe problemy przedawnienia, „Nowe Prawo” 1955, nr 1.

Kordasiewicz B., [w:] System Prawa Prywatnego, t. 2. Prawo cywilne - część ogólna, red. Z. Radwański, Warszawa 2008.

Kruszyńska-Kola J., Ratio przedawnienia, Warszawa 2020.

Kuźmicka-Sulikowska J., Idea przedawnienia i jej realizacja w polskim kodeksie cywilnym, Wrocław 2015.

Mańko R., Demons of the past? Legal survivals of the socialist legal tradition in contemporary Polish private law, [w:] Law and Critique in Central Europe. Questioning the Past, Resisting the Present, red. R. Mańko, C. Cercel, A. Sulikowski, Oxford 2016.

Radwański Z., Prawo cywilne - część ogólna, Warszawa 2007.

Stelmachowski A., Zarys teorii prawa cywilnego, Warszawa 1998.

Szer S., Prawo cywilne - część ogólna, Warszawa 1950.

Szpunar A., Uwagi o zrzeczeniu się zarzutu przedawnienia, „Rejent” 2002, nr 10.

Szpunar A., Zrzeczenie się korzystania z przedawnienia, „Palestra” 1980, nr 4-5.

realiach - pozwanemu raczej zależy na wygraniu sprawy i to jak najszybszym, więc bardziej prawdopodobne, że w tym celu skorzysta z możliwości podniesienia zarzutu przedawnienia odnośnie do dochodzonego od niego roszczenia (jeśli taka możliwość jest dostępna), aniżeli nie uczyni tego i będzie się wikłać w długotrwały proces o nie do końca pewnym wyniku (zob. J. Kuźmicka-Sulikowska, Idea przedawnienia i jej realizacja w polskim kodeksie cywilnym, Wrocław 2015, s. 463, 471-473).

22 B. Kordasiewicz, op. cit., s. 602. Zob. też rozważania w tej ostatniej kwestii w A. Torbus, Zarzut przedawnienia, [w:] Ius est a iustitia appellatum. Księga jubileuszowa dedykowana Profesorowi Tadeuszowi Wiśniewskiemu, komitet red. T. Ereciński, J. Gudowski, M. Pazdan, red. nauk. M. Tomalak, Warszawa 2017, s. 509-513, 521 oraz przywoływane tam poglądy doktryny.

Studia nad Autorytaryzmem i Totalitaryzmem 42, nr 4, 2020

(C) for this edition by CNS 
Torbus A., Zarzut przedawnienia, [w:] Ius est a iustitia appellatum. Księga jubileuszowa dedykowana Profesorowi Tadeuszowi Wiśniewskiemu, komitet red. T. Ereciński, J. Gudowski, M. Pazdan, red. nauk. M. Tomalak, Warszawa 2017.

Wolter A., Prawo cywilne - część ogólna, Kraków-Lublin 1953.

Wójcik S., Przedawnienie w prawie cywilnym po zmianie kodeksu cywilnego ustawa z 28 lipca 1990 r., „Przegląd Sądowy” 1991, nr 1-2. 